\title{
HUBUNGAN KAPABILITAS KEPEMIMPINAN KEPALA SEKOLAH DAN KINERJA GURU DENGANMUTU PEMBELAJARAN DI SEKOLAH-SEKOLAH KATHOLIK YAYASAN INSAN MANDIRI CABANG LOMBOK
}

\author{
Yohanes Kadek Ariana ${ }^{1}$, Wildan ${ }^{2}$, Dadi Setiadi ${ }^{2}$ \\ ${ }^{1)}$ Mahasiswa Program Studi Magister Administrasi Pendidikan \\ ${ }^{2)}$ DosenProgram Studi Magister Administrasi Pendidikan Universitas Mataram
}

ABSTRAK:Tujuanpenelitianini

untuk mengetahuihubunganantarakapabilitaskepemimpinankepalasekolah dan kinerja guru, baik secara sendiri-sendiri maupun secara bersama-sama dengan mutu pembelajaran di Sekolah-sekolah Katholik Yayasan Insan Mandiri Cabang Lombok. Penelitian yang dilakukan menggunakan pendekatan penelitian deskriptif kwantitatif yang melibatkan 63 orang guru sebagai sampel melalui teknik random sampling. Data dikumpulkan menggunakan angket skala Likert, dan dokumen nilai pretasi belajar siswa. Analisis data dilakukan dengan teknik analisisregresidankorelasi. Hasil analisis menunjukkan bahwahubungan antara kapabilitas kepemimpinan kepala sekolah $\left(\mathrm{X}_{1}\right)$ dengan mutu pembelajaran (Y) ditunjukkan dengan persamaan regresi $\hat{Y}=64,35+0,13 X 1$ dengan koefisien korelasi $\left(r_{\mathrm{y} 1}\right)=0,22$, untuk hubungan antara kinerja guru $\left(\mathrm{X}_{2}\right)$ dengan mutu pembelajaran $(\mathrm{Y})$ ditunjukkan dengan persamaan regresi $\hat{\mathrm{Y}}=38,55+0,43 \times 2$ dengan koefisien korelasi $\left(\mathrm{r}_{\mathrm{y} 2}\right)=0,55$ sedangkanhubungan antara kapabilitas kepemimpinan kepala sekolah $\left(\mathrm{X}_{1}\right)$ dan kinerja guru (X2) secara bersama-sama dengan mutu pembelajaran ditunjukkan dengan persamaan regresi $\hat{Y}=38,16+0,01 X_{1}+$ $0,42 X_{2}$ dan koefisien korelasi $\left(\mathrm{Ry}_{12}\right)=0,518$. Berdasarkan hasil ini disimpulkan bahwa terdapat hubungan antara kapabilitas kepemimpinan kepala sekolah, kinerja guru, baik secara sendirisendiri maupun secara bersama-sama dengan mutu pembelajaran di Sekolah-sekolah Katholik Yayasan Insan Mandiri Cabang Lombok.

\section{Kata kunci : mutu pembelajaran, kapabilitas kepemimpinan kepala sekolah, kinerja guru}

ABSTRACT: The purpose of this study was to determine the relationship between the principal leadership capability and the teachers performance, either individually or jointly with the quality of learning in Catholic Schools of Insan Mandiri Foundation Branch of Lombok. The research using quantitative descriptive research approach that involves 63 teachers as the sample through random sampling techniques.Data were collected using a Likert scale questionnaire, and the value of students achivemen document. Data analysis was performed with the technique of regression and correlation analysis. The result of analysis show that the relationship between the principal leadership capability (X1) with the quality of learning $(Y)$ indicated by the regression equation $\hat{Y}=64,35+0,13 X 1$ with correlation coefficients $\left(r_{y 1}\right)=0,22$, for the relationship between the teachers performance $(X 2)$ with the quality of learning $(Y)$ indicated by the regression equation $\hat{Y}=38,55+0,43 X 2$ with correlation coefficients $\left(r_{y 2}\right)=0.55$, while the relationship between the principal leadership capahility $(X 1)$ and the teachers performance (X2) together with the quality of learning shown by the regression equation $\hat{Y}=38,16+0,01 X_{1}+0,42 X_{2}$ and the correlation coefficient $\left(R_{y 12}\right)=0,518$. Based on these results concluded that there is a relationship between the principal leadership capability, the teachers performance, either individually or jointly with the quality of learning in Catholic Schools of Insan Mandiri Foundation Branch of Lombok.

Keywords: quality of learning, principal leadership capability, teachers performance. 


\section{PENDAHULUAN}

Sekolah merupakan salah satu bentuk organisasi pendidikan, yang dipimpin oleh seorang kepala sekolah. Kepemimpinannya diartikan sebagai proses mempengaruhi, menggerakkan, memberikan motivasi, dan mengarahkan orang-orang yang ada dalam organisasi untuk mencapai tujuan (Musfah, 2010). Oleh sebab itu kepala sekolah dituntut untuk memiliki beragam kapabilitas agar dapat bekerja secara profesional dan bertanggung jawab terhadap organisasi dan mampu bekerjadengan standar yang tinggidalam situasi baruyang terusberubah(Spry, 2004).

Menurut Duignan (2003; 2004) ada lima kapabilitas dasar yang penting dimiliki oleh setiap kepala sekolah yaitu: 1) kapabilitas pendidikan; 2) kapabilitas personal; 3) kapabilitas relasional; 4) kapabilitas intelektual; dan 5) kapabilitas keorganisasional, dan dalam penelitian ini ditambahkan satu kapabilitas yaitu kapabilitas misional(missional capabilities) yang menjadi kekhasan dari sekolah katholik. Keenam kapabilitas ini merupakan satu kesatuan yang diharapkan dapat menghasilkan kepemimpinan yang efektif, karena beberapa peneliti melaporkankan bahwa kepemimpinan kepala sekolah memainkan peran penting dalam meningkatkan pencapaian prestasi belajar siswa (Nuchiyah, 2007), dan peningkatan mutu pembelajaran (Yasnawati, dkk, 2013).

Disisi lain, guru sebagai agen perubahan diharapkan dapat mendorong terlaksananya pembelajaran sesuai dengan tujuan yang diharapkan. Kinerja guru pada dasarnya merupakan kinerja atau unjuk kerja yang dapat dilihat dan diukur berdasarkan standar tertentu, atau sesuai kriteria kompetensi yang harus dimiliki oleh setiap guru yaitu melaksanakan tugasnya sebagai pendidik.

Indikator penilaian kinerja guru menurut Rompas dan Sumarau (2011) terdiri dari : (1) menguasai bahan ajar (2) merencanakan proses belajar mengajar (3) kemampuan melaksanakan dan mengelola proses belajar mengajar, (4) kemampuan melakukan evaluasi atau penilaian. Pencapaian kinerja guru menjadi salah satu indikator keterlaksaan pembelajaran dan dapat juga digunakan sebagai refleksi dan evaluasi terhadap mutu pembelajaran. Beberapa hasil penelitian menunjukkan adanya hubungan yang signifikan antara kinerja guru dengan prestasi belajar siswa (Oni, 2014; Trianda, 2014).

Sementara, dari hasil observasi yang dilakukan di sekolah-sekolah katholik Yayasan Insan Mandiri cabang Lombok ditemukan beberapa permasalahan yang terkait dengan kapabilitas kepemimpinan kepala sekolah maupun kinerja guru, sehingga mutu pembelajaran di sekolahsekolah ini belum optimal. Berdasarkan temuan masalah-masalah ini dan menyadari pentingnya mutu pembelajaran di sekolahsekolah katholik Yayasan Insan Mandiri cabang Lombok, maka dilakukan penelitian dengan judul : "Hubungan Kapabilitas Kepemimpinan Kepala Sekolah dan Kinerja Guru dengan Mutu Pembelajaran di SekolahSekolah Katholik Yayasan Insan Mandiri “.

Tujuan penelitian ini untuk mengetahui hubungan antara kapabilitas kepemimpinan kepala sekolah dan kinerja guru, baik sendirisendiri maupun secara bersama-sama dengan mutu pembelajaran di sekolah-sekolah 
Katholik Yayasan Insan Mandiri Cabang Lombok. Hasil penelitian ini diharapkan dapat menambah khasanah ilmu pengetahuan tentang kapabilitas kepemimpinan kepala sekolah maupun kinerja guru.

\section{METODE PENELITIAN}

Penelitian ini dilaksanakan di sekolahsekolah katholik yang ada di Yayasan Insan Mandiri cabang Lombok yang melibatkan 63 guru sebagai responden yang ditentukan melalui teknik random sampling. Variabel bebas dalam peneliian ini adalah kapabilitas kepemimpinan kepala sekolah $\left(\mathrm{X}_{1}\right)$ dan kinerja guru $\left(\mathrm{X}_{2}\right)$ sedangkan variabel terikatnya adalah mutu pembelajaran (Y), dan hubungan antar variabel digambarkan seperti pada Gambar 1.

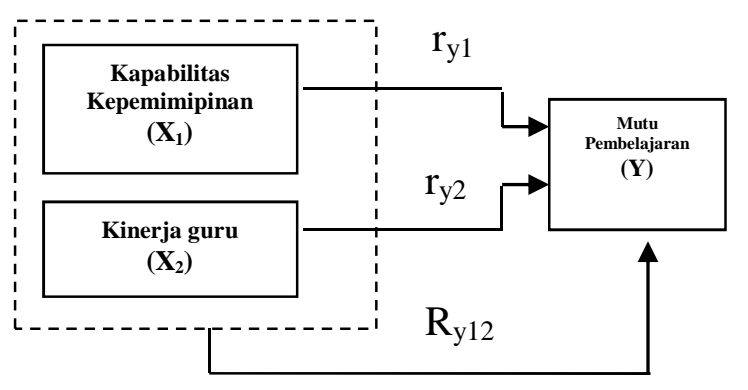

Gambar 1. Hubungan antar variabel

Data dikumpulkan menggunakan
angket dan dokumen nilai Ujian TengahSemester (UTS) pada semester genap tahun ajaran 2014/2015. Pengujian validitas menggunakan rumus Pearson Product Moment sedangkan reliabilitas menggunakan rumus koefisienAlfa Cronbac, sedangkan untuk pengujian hipotesis digunakan teknik analisis regresi dan korelasi. Data untuk uji hipotesis, terlebih dahulu diuji normalitas dan homogenitas menggunakan metode OneWayAnova.

\section{HASIL DAN PEMBAHASAN}

\section{Deskripsi data}

Hasil analisis deskriptif data tentang kapabilitas kepemimpinan kepala sekolah, kinerja guru dan mutu pembelajaran disajikan pada Tabel 1. Dari ketiga variabel, variabel kinerja guru memperoleh nilai rerata tertinggi, sementara yang terendah adalah variabel mutu pembelajaran.

Tabel 1. Hasil analisis deskriptif

\begin{tabular}{|l|l|l|l|}
\hline Variabel & $\begin{array}{l}\text { Kapabilitas } \\
\text { Kepala } \\
\text { Sekolah }\end{array}$ & $\begin{array}{l}\text { Kinerja } \\
\text { Guru }\end{array}$ & $\begin{array}{l}\text { Mutu } \\
\text { Pembe } \\
\text { lajaran }\end{array}$ \\
\hline Rata-rata & 79,72 & 84,50 & 74,82 \\
\hline Median & 81,78 & 85,33 & 74,81 \\
\hline Stan.deviasi & 14,42 & 10,78 & 13,12 \\
\hline $\begin{array}{l}\text { Nilai } \\
\text { terendah }\end{array}$ & 32,44 & 60,67 & 52,34 \\
\hline $\begin{array}{l}\text { Nilai } \\
\text { terbesar }\end{array}$ & 99,11 & 99,33 & 92,17 \\
\hline Responden & 63 & 63 & 63 \\
\hline
\end{tabular}

Hasil pengujian normalitas terhadap variabel bebas $\left(\mathrm{X}_{1}\right),\left(\mathrm{X}_{2}\right)$ dan variabel terikat (Y), menunjukkan bahwa semua data berdistribusi normal (Tabel 2). Selanjutnya dari hasil uji homogenitas diperoleh nilai $\mathrm{F}_{\text {hitung }}=1,208<\mathrm{F}_{\text {tabel }}=1,524$ untuk variabel kapabilitas kepemimpinan kepala sekolah, dan nilai $F_{\text {hitung }}=1,403<\mathrm{F}_{\text {tabel }}=1,524$ untuk variabel kinerja guru, dengan demikian varian data adalah homogen.

Tabel 2. Hasil Pengujian Normalitas Variabel Penelitian 


\begin{tabular}{|c|c|c|c|c|}
\hline \multirow[b]{2}{*}{ No } & \multirow[b]{2}{*}{ Variabel } & \multicolumn{2}{|c|}{ Harga } & \multirow{3}{*}{$\begin{array}{l}\text { Keteran } \\
\text { gan }\end{array}$} \\
\hline & & $\mathbf{F}_{\text {hitun }}$ & $\mathbf{F}_{\text {tabe }}$ & \\
\hline & & $\mathrm{g}$ & 1 & \\
\hline \multirow[t]{2}{*}{1} & Kapabilitas & 870 & 11,0 & \multirow{2}{*}{ Normal } \\
\hline & Kepsek $\left(\mathrm{X}_{1}\right)$ & & 7 & \\
\hline \multirow[t]{2}{*}{2} & \multirow{2}{*}{$\operatorname{Kinerja} \operatorname{Guru}\left(\mathrm{X}_{2}\right)$} & \multirow{2}{*}{-98.70} & 11,0 & Norma \\
\hline & & & 7 & 1 \\
\hline \multirow[t]{2}{*}{3} & Mutu & & 110 & Norma \\
\hline & Pembelajaran (Y) & & 11,0 & \\
\hline
\end{tabular}

PENGUJIAN HIPOTESIS

Berdasarkan hasil perhitungan diperoleh koefisien regresi b sebesar 0,13, dan konstanta a sebesar 64,35, sehingga bentuk hubungan antara kapabilitas kepemimpinan kepala sekolah (X1) dengan mutu pembelajaran (Y) ditunjukkan oleh persamaan $\hat{Y}=64,35+0,13 X_{1} \quad$ (Gambar 2). Hasil uji signifikansi dan linearitas membuktikan bahwa persamaanregresi tersebut signifikan dan bersifat linier ( $p=$ $0,045<0,05)$, dengan koefisien korelasi tunggal sebesar $\left(\mathrm{r}_{\mathrm{y} 1}\right)=0,223$, koefisien korelasi parsial $=0,020$ dan koefisien diterminasi $r_{\mathrm{yl}}^{2}=0,05$.

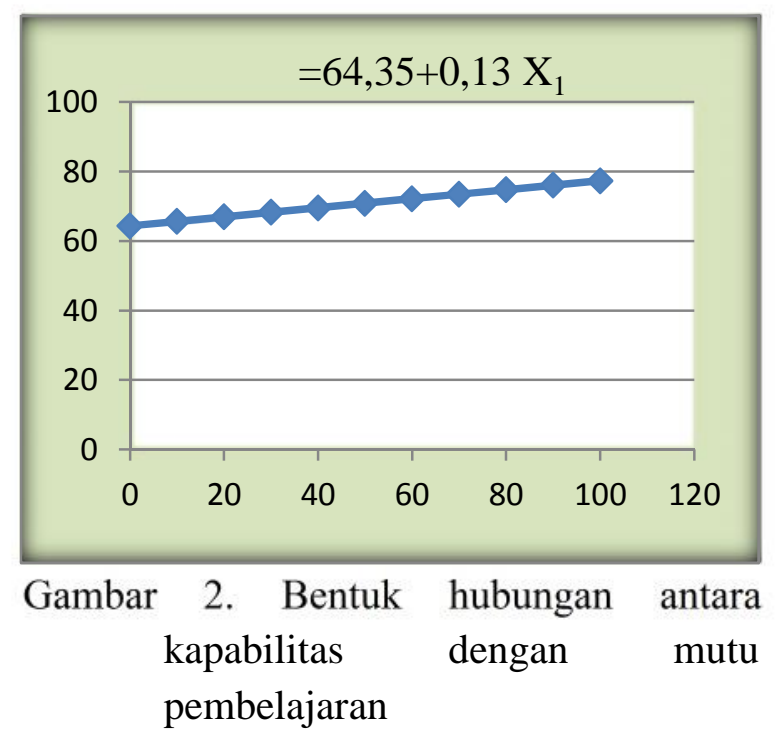

Bentuk hubungan antara variabel kinerja guru (X2) dengan mutu pembelajaran (Y)ditunjukkan melalui persamaan $\hat{Y}=$ $38,55+0,43 X_{2}$ (Gambar 3), setelah melalui uji signifikansi maupun linearitas menunjukkan bahwa persamaan regresi tersebut signifikan dan bersifat linier $(\mathrm{p}=$ $0,000<0,05)$, dengan koefisien korelasi tunggal sebesar $\left(\mathrm{r}_{\mathrm{y} 2}\right)=0,552$, koefisien korelasi parsial $=0,518$, dan koefisien determinasi $\mathrm{r}_{\mathrm{y} 1}^{2}$ sebesar 0,304 .

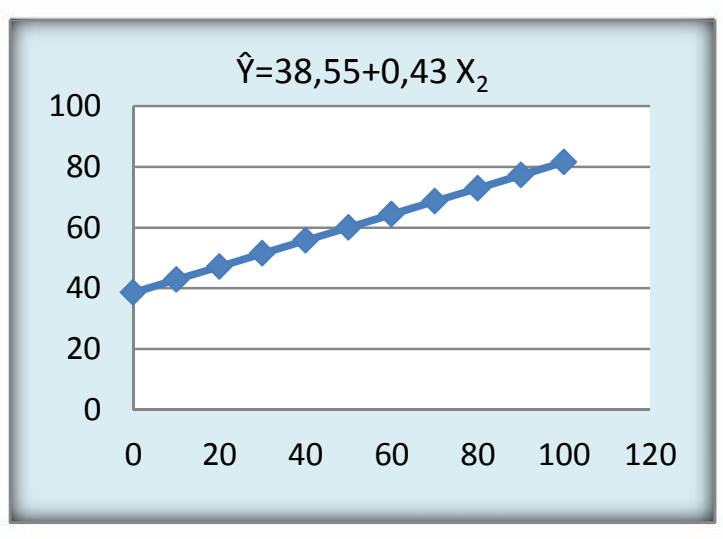

Gambar 3. Bentuk hubungan antara kinerja guru dengan mutu pembelajaran

Sementara bentuk hubungan antara variabel $\mathrm{X}_{1}$ dan $\mathrm{X}_{2}$ secara bersama-sama dengan $Y$ ditunjukkan melalui persamaan $\hat{Y}=38,16+0,01 X_{1}+0,42 X_{2}$, (Gambar 3) dan hasil uji menyimpulkan bahwa persamaan regresi tersebut signifikan dan bersifat linier $(\mathrm{p}=0,000<0,05)$. Dari hasil perhitungan koefisien korelasi diperoleh nilai $\mathrm{R}_{\mathrm{y} 12}=0,538$ dan koefisien determinasi $\mathrm{R}_{\mathrm{y} 12}^{2}=$ 0,3046, sehingga kekuatan hubungan kedua variabel termasuk katagori sedang. 


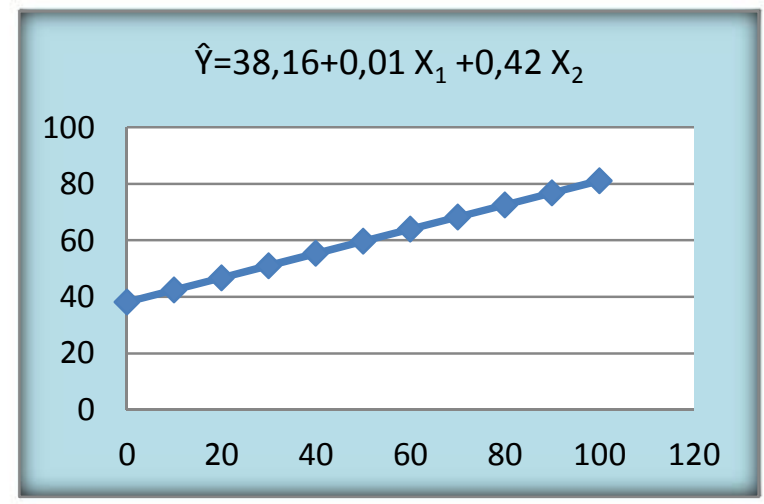

Gambar 4. Bentuk hubungan antara kapabilitas, kinerja guru dengan mutu pembelajaran

\section{PEMBAHASAN}

Berdasarkan hasil pengujian hipotesis menunjukkan bahwa semua hipotesis statistik (Ho) dalam penelitian ini ditolak pada taraf signifikansi 0,05 dengan demikian antara variabel - variabel yang diteliti terdapat hubungan positif yang signifikan, tetapi kekuatan hubungan antara variabel-variabel yang diteliti tidak sama. Pembahasan masingmasing hubungan antar variabel diuraikan sebagai berikut :

\section{(1) Hubungan antara kapabilitas kepemimpinan kepala sekolah dengan mutu pembelajaran di sekolah-sekolah Katholik Yayasan Insan Mandiri Cabang Lombok}

Berdasarkan hasil pengujian hipotesis,dapat disimpulkan bahwa terdapat hubungan yang positif antara kapabilitas kepemimpinan kepala sekolah dengan mutu pembelajaran di sekolah-sekolah Katholik Yayasan Insan Mandiri Cabang Lombok, namun kekuatan hubungan kedua variabel tersebut sangat lemah, karena hanya 5\% mutu pembelajaran dikonstribusi oleh kapabilitas kepemimpinan Kepala Sekolah.Hasil penelitian ini sejalan dengan hasil penelitian
Quin dkk (2015) yang menemukan nilai $\mathrm{r}_{\mathrm{y} 1}^{2}$ sebesar 0,049 untuk hubungan antara kepemimpinan kepala sekolah dengan prestasi belajar siswa. Sementara Siegrist dkk, (2009) menemukan bahwa praktek kepemimpinan kepala sekolah tidak berdampak pada prestasi akademik, demikian juga Gieselmann (2009) menyatakan bahwa kepemimpinan kepala sekolah tidak dapat meramalkan prestasi akademik siswa.

Apabila dilihat dari tanggapan responden terhadap enam dimensi kapabilitas kepemimpinan kepala sekolah, dimensi yang paling rendah adalah kapabilitas organisasional sedangkan yang tertinggi adalah kapabilitas misional (Gambar 5).

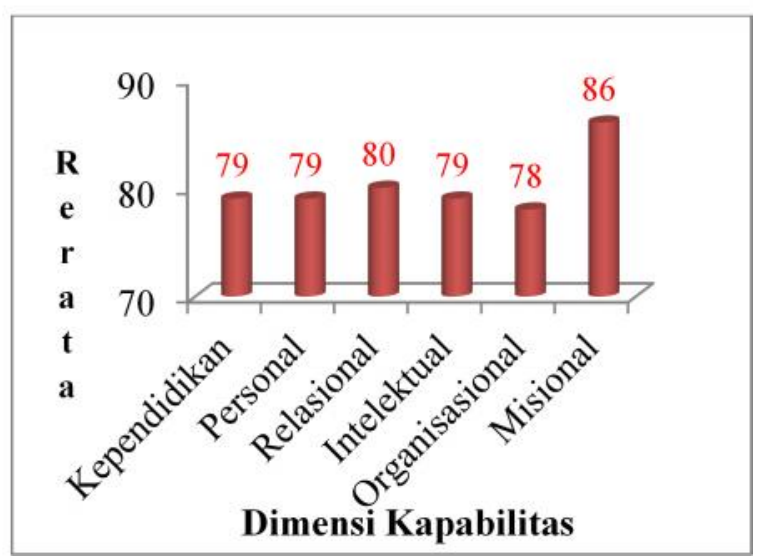

Gambar 5. Profil kapabilitas kepemimpinan kepala sekolah

Fakta ini menunjukkan bahwa lemahnya hubungan antara kapabilitas kepemimpinan dengan mutu pembelajaran lebih disebabkan oleh rendahnya kapabilitas organisasional karena kapabilitas ini berfokus pada prestasi sekolah yang menuntut kemampuan kepala sekolah dalam mensupport pengembangan sekolah secara terus menerus melalui manajemen SDM, keuangan, dan fasilitas pembelajaran. Menurut Sudarya dan Suratno 
(2009)kapabilitas organisasi mendasari bentuk orientasi pencapaian (achievement orientation) kepemimpinan kepala sekolah dalam kaitannya dengan efektivitas, efisiensi dari proses, hasil dan lingkungan belajar di sekolah yang dipimpinnya. Senada dengan hal ini, Sebastian dan Allensworth (2015) mengatakan bahwa pengajaran di dalam kelas ada kaitannya dengan kepemimpinan kepala sekolah.

Rendah kontribusi kapabilitas kepemimpinan organisasi kepala sekolah menggambarkan bahwa kemampuan kepala sekolah dalam menjalankan peran sebagai administrator/manajer belum optimal terutama pada aspek yang terkait dengan pembelajaran, antara lain kemampuan mengkaitkan hasil praktik pembelajaran dan pengembangan professional ke dalam konteks kinerja sekolah secara menyeluruh, kemampuan memanfaatkan umpan balik dalam upaya mengembangan orientasi sekolah ke depan, dan kemampuan melaksanakan monitoring secara efektif dan akuntabel tentang sistem perencanaan, manajemen dan pelaporan.

\section{(2) Hubungan antara kinerja guru dengan mutu pembelajaran di sekolah-sekolah Katholik Yayasan Insan Mandiri Cabang Lombok}

Hasil pengujian hipotesis menyimpulkan bahwa terdapat hubungan yang positif antara kinerja guru dengan mutu pembelajaran di sekolah-sekolah Katholik Yayasan Insan Mandiri, dengan kekuatan hubungan dalam katagori sedang. Hasil ini, sejalan dengan penelitian yang dilakukan oleh Trianda (2014) bahwa ada pengaruh kinerja guru terhadap prestasi belajar siswa walaupun pengaruhnya relatif kecil.

Berdasarkan anggapan responden kinerja yang paling tinggi terkait dengan kemampuan guru untuk merencanakan kegiatan pembelajaran, sedangkan kinerja yang paling rendah terkait dengan kemampuan guru mengadakan evaluasi pembelajaran (Gambar 6).

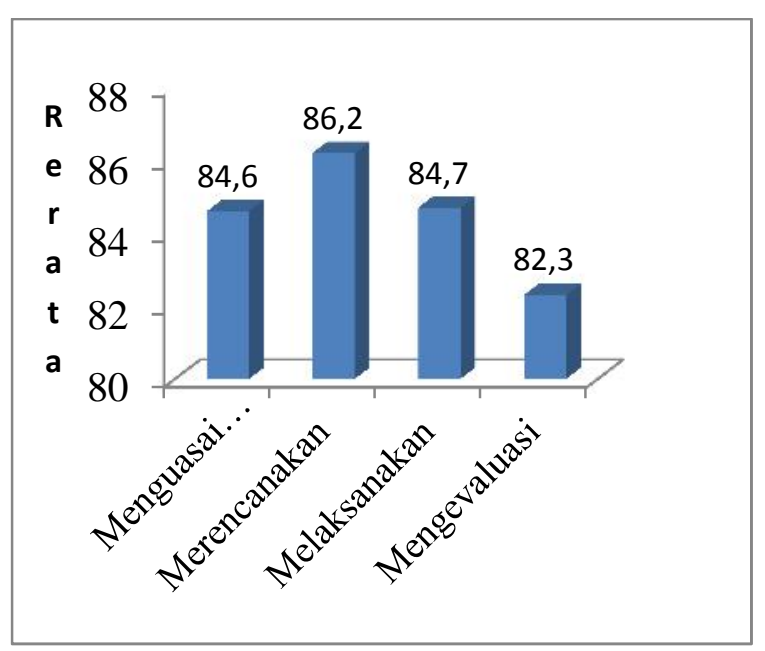

Gambar 6. Profil Kinerja Guru

Apabila ditinjau dari masing-masing indikator diperoleh fakta bahwa indikator pelaksanaan kegiatan belajar mengajar mendapatkan skor paling rendah terutama kemampuan guru untuk menggunakan media yang bervariasi serta untuk mengimplementasikan beragam metode dan pendekatan selama proses pembelajaran berlangsung. Hasil ini diperkuat oleh Akinfe dkk (2012) yang menyatakan bahwa metode pembelajaran yang digunakan guru secara signifikan berpengaruh terhadap hasil belajar siswa, demikian pula menurutRifandi (2013) bahwa mutu pembelajaran dipengaruhi secara positif dan signifikan oleh media pembelajaran dan fasilitas pembelajaran.

Fakta lain yang ditemukan dalam penelitian ini bahwa kemampuan guru dalam 
mengadakan evaluasi pembelajaran terutama dalam hal penggunaan pendekatan penilaian yang sesuai dengan potensi siswa masih rendah, serta guru kurang memanfaatkan hasil belajar siswa untuk melakukan evaluasi terhadap proses pembelajaran.

Berdasarkan uraian ini, dapat disimpulkan bahwa kinerja guru di sekolah sekolah katholik yayasan insan mandiri cabang Lombok masih belum optimal, sehingga belum mampu memberikan kontribusi yang kuat terhadap mutu pembelajaran.

\section{(3) Hubungan antara kapabilitas kepemimpinan kepala sekolah dan kinerja guru secara bersama-sama dengan mutu pembelajaran di sekolah-sekolah Katholik Yayasan Insan Mandiri}

Mutu pembelajaran di sekolah-sekolah Katholik Yayasan Insan Mandiri termasuk katagori sedang, hal ini diungkapkan oleh $60 \%$ responden, namun yang lebih dominan pengaruhnya dari variabel kinerja guru. Hubungan antara kapabilitas kepemimpinan kepala sekolah, kinerja guru secara bersamasama dengan mutu pembelajaran termasuk dalam katagori sedang, dan dari hasil analisis diketahui bahwa kinerja guru lebih dominan pengaruhnya dibanding kapabilitas kepemimpinan kepala sekolah.

Hasil ini sejalan dengan hasil penelitian yang dilaporkan oleh Valentina dkk (2014) bahwa ada hubungan yang positif, erat dan signifikan antara kinerja guru dalam merencanakan pembelajaran, mengelola dan melaksanakan pembelajaran serta mengevaluasi pembelajaran dengan hasil belajar siswa. Indikator kinerja guru yang paling baik adalah pada aspek perencanaan pembelajaran.

Menurut pendapat Mulyasa (2010) perencanaan yang baik akan sangat membantu pelaksanaan pembelajaran, karena baik guru maupun peserta didik mengetahui dengan pasti tujuan yang ingin dicapai dan cara mencapainya.

Implikasi dari hasil penelitian ini adalah jika mutu pembelajaran menurun atau rendah maka salah satu upaya yang efektif untuk meningkatkan mutu pembelajaran adalah dengan memperbaiki kinerja guru, mulai dari kemampuan guru dalam menyusun perencanaan pembelajaran pengelolaan dan pelaksanaan pembelajaran serta kemampuan melakukan evaluasi pembelajaran.

Disisi lain, upaya untuk meningkatkan kapabilitas kepemimpinan kepala sekolah harus terus ditingkatkan. Walaupun dalam penelitian ini pengaruhnya relatif lemah dalam meningkatkan mutu pembelajaran, tetapi beberapa hasil penelitian lain menunjukkan bahwa kapabilitas kepemimpinan kepala sekolah mempunyai pengaruh lebih kuat terhadap aspek kinerja guru (Rompas dan Sumarauw, 2011) maupun terhadap iklim kerja di sekolah yang dipimpinnya (Andi Putra dkk, 2014).

Kepala sekolah sebagai pimpinan tertinggi di sekolah, kepemimpinannya diharapkan dapat mendorong kemajuan sekolahnya. Kepemimpinan kepala sekolah dalam organisasi pendidikan diartikan sebagai proses mempengaruhi, menggerakkan, memberikan motivasi dan mengarahkan orang-orang yang ada dalam organisasi pendidikan untuk mencapai tujuan. Banyak hasil penelitian mengindikasikan bahwa munculnya sekolah berprestasi yang 
juga sering disebut sebagai sekolah yang berhasil (successful schools), atau sekolah yang baik (good schools), tidak dapat dilepaskan dari peranan yang dimainkan kepala sekolah sebagai pemimpin pembelajaran (Surachmi, 2011).

\section{KESIMPULAN, IMPLIKASI DAN SARAN}

\section{KESIMPULAN}

Berdasarkan hasil analisis data dan pembahasan yang telah diuraikan, maka beberapa kesimpulan dari penelitian ini adalah:

(1) Terdapat hubungan yang positif yang signifikan antara kapabilitas kepemimpinan kepala sekolah dengan mutu pembelajaran di sekolah-sekolah Katholik Yayasan Insan Mandiri yang ditunjukkan oleh persamaan garis regresi $\hat{Y}=64,35+0,13 X 1$. Namun kekuatan hubungan antara kedua variabel termasuk katagori lemah , yang ditunjukkan oleh koefisien korelasi $r_{\mathrm{y} 1}=0,223(\alpha=0,05)$ dan koefisien determinasi $\mathrm{r}_{\mathrm{y} 1}^{2}=4,9 \%$. Lemahnya hubungan antara kapabilitas kepemimpinan kepala sekolah dengan mutu pembelajaran diasumsikan karena dimensi kapabilitas organisasional yang terkait dengan aspek pembelajaran masih rendah.

(2) Terdapat hubungan yang positif yang signifikan antara kinerja guru dengan mutu pembelajaran di sekolah-sekolah Katholik Yayasan Insan Mandiri, yang ditunjukkan oleh persamaan garisregresi $\hat{Y}=38,55+$ $0,43 \times 2$, dan kekuatan hubungan antara kedua variabel termasuk katagori sedang, dengan koefisien korelasi sebesar0,552 $(\alpha=0,05)$ dan koefisien determinasi sebesar $30,43 \%$. Belum optimalnya hubungan kedua variabel ini diasumsikan karena kinerja guru yang terkait dengan menggunakan media pembelajaran dan penggunaan beragam metode selama proses pembelajaran berlangsung, serta kemampuan pemanfaatan hasil belajar siswa untuk melakukan evaluasi terhadap proses pembelajaranbelum optimal.

(3)Terdapat hubungan yang positif yang signifikan antara kapabilitas kepemimpinan kepala sekolah dan kinerja guru secara bersama-sama dengan mutu pembelajaran di sekolah-sekolah Katholik Yayasan Insan Mandiri, yang ditunjukkan oleh persamaan garis regresiY $\hat{Y}=38,16+$ $0,01 X_{1}+0,42 X_{2}$, dan kekuatan hubungan antara kedua variabel termasuk katagori sedang dengan koefisien korelasi sebesar 0,5519 $(\alpha=0,05)$ dan koefisien determinasi sebesar $30,46 \%$. Pengaruh kinerja guru terhadap mutu pembelajaran di sekolah-sekolah Katholik Yayasan Insan Mandiri lebih dominan dibanding pengaruh kapabilitas kepemimpinan kepala sekolah.

\section{IMPLIKASI HASIL PENELITIAN}

Bertitik tolak dari hasil ini, maka beberapa implikasi baik secara teoritik maupun secara empirik untuk meningkatkan mutu pembelajaran di sekolah -sekolah Katholik Yayasan Insan Mandiri, dapat ditempuh melalui upaya-upaya perbaikan sebagai berikut:

\section{(1) MeningkatkanKapabilitasKepemimpi nan Kepala Sekolah}


Rendahnya pengaruh kapabilitas kepemimpinan kepala sekolah terhadap mutu pembelajaran di sekolah-sekolah Katholik Yayasan Insan Mandiri disebabkan oleh lemahkan kemampuan kepala sekolah dalam bidang organisasi. Oleh karena itu programprogram yang perlu ditempuh diantaranya :

(a) Pelatihan kepemimpinan bagi kepala sekolah

(b) Pelatihan manajerial untuk meningkatkan kemampuan manajemen organisasi

(c) Studi banding ke institusi pendidikan yang lebih unggul untuk memperoleh pengalaman dalam bidang manajemen sekolah

(d) Workshop untuk meningkatkan kemampuan dalam bidang pembelajaran

(e) Bila memungkinkan kepala sekolah melanjutkan pendidikan ke jengjang yang lebih tinggi.

\section{(2) Meningkatkan Kinerja Guru}

Kinerja guru diartikan sebagai prestasi kerja yang dicapai guru dalam menjalankan tugas mengajar, terutama dalam bidang (a) penguasaan bahan ajar, (b) kemampuan merencanakan kegiatan pembelajaran, (c) kemampuan mengelola dan melaksanakan pembelajaran dan (d) kemampuan mengadakan evaluasi pembelajaran. Dari keempat kemampuan itu yang masih belum optimal adalah kemampuan guru dalam mengadakan evaluasi dan memanfaatkan hasil belajar untuk evaluasi proses pembelajaran. Kemampuan guru menggunakan media dan mengimplementasikan beragam metode serta pendekatan selama proses pembelajaran berlangsung sangat rendah. Oleh sebab itu perlu upaya yang dilakukan oleh kepala sekolah untuk meningkatkan kinerja guru melalui :

(a) Workshop untuk menganalisis hasil evaluasi pembelajaran untuk meningkatkan kemampuan guru dalam melaksanakan evaluasi.

(b) Workshop penyusunan perangkat pembelajaran pada awal tahun ajaran dan evaluasi pada akhir tahun ajaran.

(c) Mengadakan MGMP di sekolah supaya semua guru bisa terlibat, atau mengikuti MGMP ditingkat provinsi atau LPMP.

(d) Mengikuti kegiatan seminar untuk meningkatkan pengetahuan terutama yang terkait dengan implementasi berbagai metode pembelajaran.

(e) Mengikuti pelatihan untuk meningkatkan kemampuan dalam mengembangkan media pembelajaran

(f) Mengikuti kegiatan pelatihan IT

(g) Kepala sekolah meningkatkan kegiatan supervisi akademis maupun klinis serta diskusi dengan guru-guru untuk menemukan solusi terhadap masalah pembelajaran.

(h) Mengikuti pendidikan lanjut pada jenjang yang lebih tinggi untuk menambah ilmu pengetahuan.

\section{SARAN}

Berdasarkan kesimpulan dan implikasi yang telah diuraikan, maka saransaran yang dikemukakan ditujukan pada pihak terkait antara lain:

1. Bagi kepala sekolah di Yayasan Insan Mandiri diharapkan: (a) meningkatkan kapabilitas kepemimpinan organisasional terutama upaya mengarahkan orientasi sekolah ke depan dengan standar prestasi yang tinggi, dan (b) meningkatkan 
kegiatan supervisi agar kinerja guru semakin meningkat.

2. Bagi guru-guru di sekolah katholik Yayasan Insan Mandiri, diharapkan dapat meningkatkan kemampuannya terutama dalam mengimplentasikan berbagai metode pembelajaran serta mengembangkan media pembelajaran yang kreatif.

Bagi pengelola Yayasan Insan Mandiri, diharapkan hasil penelitian sebagai bahan untuk merumuskan kebijakkan yang terkait dengan (a) kriteria perekrutan kepala sekolah dan guru-guru di Yayasan, (b) dukungan terhadap program-program peningkatan kemampuan kepala sekolah dan guru, serta (c ) penguatan sistem manajemen di sekolahsekolah.

\section{DAFTAR PUSTAKA}

Akinfe, E., Olofinniyi, O. E., and Fashiku, C. O. 2012. Teachers' Quality as Correlates of Students' Academic Performance in Biology in Senior Secondary Schools in Ondo State, Nigeria. Online journal of education research. 1(Issue 6)

Andi Putra, M. K, Haris,I.A dan Meitriana, M.A. 2014. Pengaruh Persepsi Guru Tentang Gaya Kepemimpinan Kepala Sekolah Dan Iklim Kerja Terhadap Kinerja Guru . Online. http://ejournal. undiksha.ac.id/index.php/ JJPE/ article/download/2064/1801. Maret 2015)

Duignan, P. 2003. Formation of capable, influential and authentic leaders for times of uncertainty. Makalah
dalamThe Australian Primary Principals' Association National Conference, Adelaide.

Duignan, P. 2004. "Forming capable leaders: from competence to capabilities". New Zealand Journal of Educational Leadership, 19, (2), 5-13.

Gieselmann, S. 2009. Principals and school factors that impact elementary school student achievement. MidWestern Educational Researcher. 22(2), 16-22

Oni. J.O. 2014. Teacher Quality and Student Academic Achievement in Basic Technology in Junior Secondary Schools in South-West, Nigeria. Journal of Educational and Social Research. 4(3) : 397-402

Mulyasa. 2010. Implementasi Kurikulum Tingkat Satuan Pendidikan. Jakarta: Bumi Aksara.

Musfah, Jejen. 2010 Kepemimpinan Kepala Sekolah. Online: http://mpjurnalpendidikanislam.com/doc $\% 20$ baru/2010/3/9.pdf, diunduh tangal 25 Januari 2015

Nuchiah, N. 2007. Pengaruh Kepemimpinan Kepala Sekolah dan Kinerja Mengajar Guru Terhadap Prestasi Belajar Siswa. Jurnal Pendidikan Dasar. 5, (7).

Quin, J.F., Deris, A.R., Bischoff, G., Johnson, J.T. 2015. The Correlation Between Leadership, Culture, and Student Achievement. The Online Journal of New Horizons in Education. 5(2) : 55-62 
Rifandi,A. 2013. Mutu Pembelajaran Dan Kompetensi Lulusan Diploma III Politeknik. Cakrawala Pendidikan, 32 (1): 125-138

Rompas dan Sumarauw.2011. "Pengaruh Kepemimpinan Kepala Sekolah Terhadap Peningkatan Efektivitas Kerja Guru-Guru Di SMK Kristen Getsemani Manado. ED VOKASI, Jurnal Pendidikan Teknologi dan Kejuruan. 2, (2): 28-37

Sebastian, J and Allensworth, E. 2015. The Influence of Principal Leadership on Classroom Instruction and Student Learning. Educational Management Administration \& Leadership. 43: 490-506

Siegrist, G., Weeks, W., Pate, J., \& Monetti, D. 2009. Principals' experience, educational level, and leadership practices as predictors of Georgia high school graduation test results. Journal of Philosophy and History of Education. 59 (1): 174-179

Stephenson, J. 2000. Corporate capability: implications for the style and direction of work-based learning. Working Paper 99-114. Sydney: Research Centre for Vocational Education and Training, University Technology Sydney. [Online). Tersedia http://www.sacle .edu.au/ leaderframework.html (22 February 2015)

Spry,G. 2004. A Framework for Leadership in Qld Catholic Schools: A Report, March 2004. Strathfield, NSW: Australian Catholic University.
Sudarya, Y dan Suratno, T. 2009. Dimensi Kepemimpinan Kepala Sekolah. Online diunduh http://File.Upi.Edu/Direktori/Jurnal/ Pendidikan_Dasar/Nomor_12Oktober_2009/Dimensi_Kepemimpi nan_Kepala_Sekolah.pdf(25 Januari 2015)

Trianda, S.T., Thomas, Y danAchmadi. 2014. Pengaruh Kinerja Guru terhadapHasilBelajarSiswaKelas $\mathrm{X}$ padapelajaranekonomi di SMA. JurnalPendidikandanPembelajaran. $3(10)$

Surachmi, S. 2011 Efektivitas Dimensi Internal Kepala Sekolah Dalam Kepemimpinan Pembelajaran. Cakrawala Pendidikan, 30 (3) : 433 448

Valentina, P.Y., Sumadi, danSuwarni, N. 2014. Hubungan Kinerja Guru Dengan Hasil Belajar Geografi Siswa. (30 juni 2015)

Yasnawati, G.K, Yudana, M dan Natajaya, N.2013. "Kemampuan Manajerial, Motivasi Kepala Sekolah dan Profesionalisme Guru Terhadap Kualitas Pembelajaran Pada Para Guru Di SMA Se-Kecamatan Sukasada". e Journal Program Pascasarjana Universitas Pendidikan Ganesha Program Sudi Administrasi Pendidikan.4. Januari 2015) 